\title{
WHY ARE CULTURAL LANDSCAPES OF VARIOUS VALUES? THINKING ABOUT HERITAGE LANDSCAPE EVALUATION AND MONITORING TOOLS
}

\author{
SOFIA CAPELO ${ }^{1}$, FILIPE THEMUdO BARATA ${ }^{2}$, \\ JOSÉ MANUEL DE MASCARENHAS ${ }^{3}$
}

${ }^{1}$ Universidade de Évora, Colégio Verney, Apartado 94, 7002-554 Évora, Portugal; scapelo@uevora.pt

${ }^{2}$ CIDEHUS-UE, fthbarata@netcabo.pt

${ }^{3}$ CIDEHUS-UE, mascarenhas_jm@sapo.pt

Received: $7^{\text {th }}$ September 2010 , Accepted: $6^{\text {th }}$ June 2011

\begin{abstract}
The aim of this paper is to contribute towards the successful management of heritage landscapes. Many cultural landscapes represent high heritage value and should be classified as heritage landscapes; therefore, special tools should be considered to be used in managing them. These landscapes should be evaluated according to heritage science criteria and good practice guidelines should be established. Several useful heritage landscape evaluation criteria were identified and characterised, and their relative importance was analysed, enabling the establishment of a heritage value hierarchy by means of a weighted linear combination. This is significant in the context of land management measures for countryside valorization promoting rural development.

However, this approach also requires awareness of the link between the present cultural landscape and the history of the people that have interacted with the area involved. This is also important for the establishment of a priority ranking system for monitoring criteria indicators. A method for doing this is also proposed by the authors.
\end{abstract}

Keywords: landscape, heritage, evaluation criteria, monitoring indicators.

\section{INTRODUCTION}

Heritage is an asset we have inherited which will be bequeathed to future generations; it is of great interest to all societies and, to some extent, materialises a past, to be safeguarded in the present and the future (Audrerie, 1997); it constitutes a means of preserving the memory of a community. This is why the concept has both an empirical and a transcendental meaning.

Heritage exists physically as objects, buildings and landscapes, and "in the mind in the form of memories, attitudes and imagination that endow the material manifestations with meaning" (Merriman, 1996). In recent decades, the concept has been developed and its meaning has been extended in the social consciousness from architectural structures to sites and from the urban context to nature and the environment, which has gained so much importance that, for some, it has become a cultural asset. If we define heritage value as "a 
set of positive characteristics or qualities perceived in cultural objects or sites by certain individuals or groups" (De la Torre and Mason, 2002), these aspects are not immutable in a changing context. As the referred authors state, "the articulation and understanding of values have acquired greater importance when heritage decisions are being made about what to conserve, how to conserve it, where to set priorities, and how to handle conflicting interests" (De la Torre and Mason, 2002).

The assessment of landscape heritage value and monitoring are important elements of the processes of conservation planning and management. Indicators are a valuable tool which should be used for monitoring heritage quality since they "relate to issues or conditions which are influenced by some action or trend" (Eagles et al., 2002).

Few studies of heritage landscapes with land management goals have been carried out, and we would like to highlight some issues for debate in the field and present some methodological issues associated with application trials. For the purposes of simplification, we have selected four case-studies for the evaluation of the use of monitoring indicators.

At the same time, it should be borne in mind that societies are interested in preserving and taking advantage of cultural landscapes with heritage value, including their use for recreational purposes.

\section{Reflections on what constitutes a heritage landscape}

According to the Cultural and Natural Heritage Convention held by UNESCO in 2005 and also to many experts, "cultural landscape" can be considered as being "illustrative of the evolution of human society and settlement over time, under the influence of the physical constraints and/or opportunities presented by their natural environment and of successive social, economic and cultural forces, both external and internal' (WHC, 2005). From an operational point of view, this concept is intended to be dynamic since the cultural landscape should be a product of a long-term, scientifically demonstrable nature/human interactive process (Fowler, 2006). From this perspective, exploring how heritage requires a new focus on landscape, David Lowenthal (1993) argues that 'the word landscape subsumes three vital concepts: nature as fundamental heritage in its own right; environment as the setting of human action and sense of place as awareness of local difference and appreciation of ancestral roots'.

Attempting to provide a historical context, Lowenthal (1993) states that 'linkages of present with past are felt to need not just isolated heritage icons but the cultural landscape's embedding framework'. Therefore, the present character of many of these landscapes is a 'palimpsest of elements from the past and present' (Aplin, 2007), in which the persistence of plans has been more or less determinative.

Several types of values can be conferred on cultural landscapes, and the way in which they are assigned depends on individuals or groups of actors. Heritage value is one of these, and the most highly-valued cultural landscapes may be designated "heritage landscapes".

Regarding the UNESCO definition, it should be borne in mind that heritage landscapes represent a high level of typological diversity since: 1) they reveal specific interactions between humans and their environment; 2) they are associated with living traditional cultures; 3) they preserve traces of human land use types which have disappeared (WHC, 2004, cit. by Aplin, 2007).

The classification of different types of landscape also had an operational aim: all UNESCO members would be able to put forward for classification a landscape of any kind with outstanding features that fitted one of the types, so that every member could have its own classified landscape. 
It has taken a significant degree of political will to preserve the natural and cultural heritage, while as far as methodological and conceptual aspects are concerned the platform is fragile. As there is a wide range of types of landscape, it should have been easy to establish a classification system; but in fact by 2009 only 64 landscapes had been classified by UNESCO. There are currently two problems: firstly, how to deal with and manage 2005-convention landscapes types in view of the high standards imposed by the UNESCO experts committee; secondly, the difficulty of raising awareness of the different types. In fact, "hidden landscapes" are defined as those from which natural and cultural elements are disappearing, whose structural features are seriously threatened by modern society and mainstream land management and in which ancient marks and remains are vanishing; these landscapes are especially difficult to protect and preserve. It is right that heritage should aid growth and development, but at the same time it is actually disappearing!

One of the main aims of this paper is to address this issue; control and monitoring of heritage values should be targeted at all heritage types including hidden landscapes.

\section{Selected heritage landscape case-studies}

For the purpose of conducting methodological trials, four contrasting landscapes were selected as case-studies: three in the area surrounding the city of Évora (in the central Alentejo region of Portugal) and another one in the Douro valley (in Northern Portugal), designated as follows: the "montado" system, characterized by the presence of holm-oaks and/or cork-oaks; the Roman cadastral system, dating from Augustan times, in the area around Ebora (Roman Évora); the Mitra convent estate kitchen-garden; and the Douro valley terraced-vineyard landscape.

The "montado" is a typical south-west Iberian Peninsula landscape, traditionally associated with agro-silvo-pastoral systems in which open formations of cork-oaks and/or holm-oaks (and possibly other kinds of trees), pure or mixed, composed the treelike layer under what a rotation of crops / fallows / pastures takes place. These formations are currently protected by national and European law (Fig. 1).

Fig. 1: Cork oak montado in Évora surroundings (photo J. M. de Mascarenhas 2005).

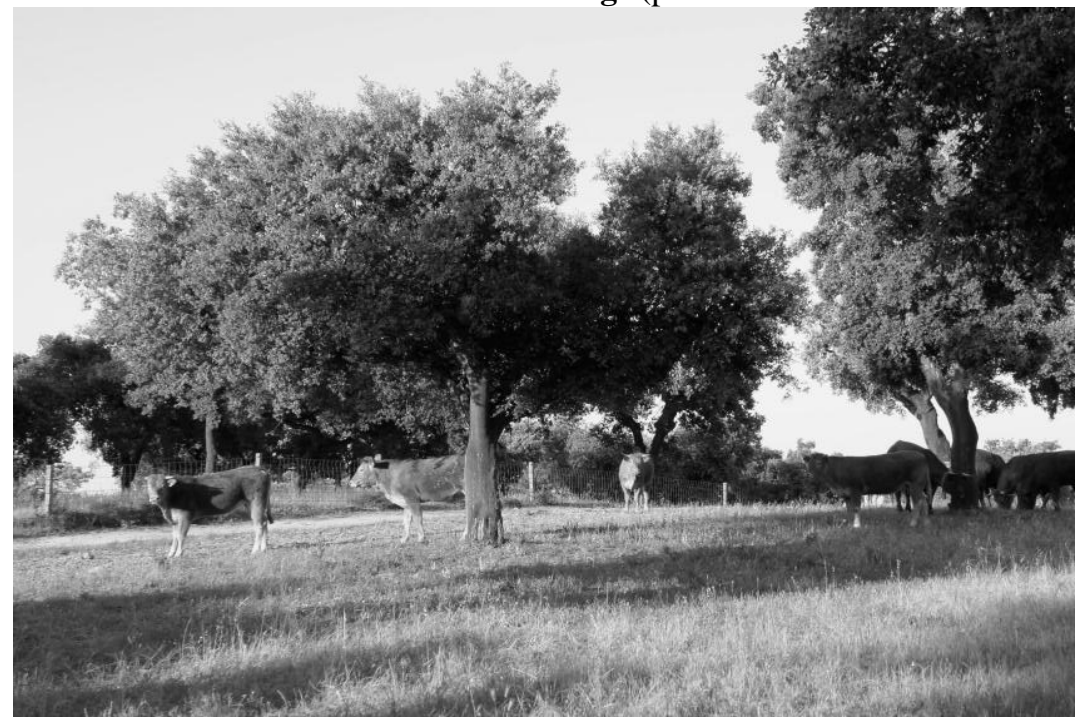


In the Roman era, when Évora (or Ebora Liberalitas Iulia, as Pliny called it) became a municipium (Augustan times), a field network system, or cadastration, was established. Traces of a probable cadastre structure have been identified, oriented NO/SE (30-31 $)$, with a theoretical matrix of 20 x 20 actus (with an area of approximately $710 \mathrm{~m} \times 710 \mathrm{~m}$ ). Many of the cadastre boundaries are still materialized by various features such as roads, ditches, stone walls, property boundaries and marks, and water channels, among others (Fig. 2).

Fig. 2: Remains of the Roman Augustan cadastral network in Évora surrounding area (following M. Clavel-Lévêque et al. 1995).

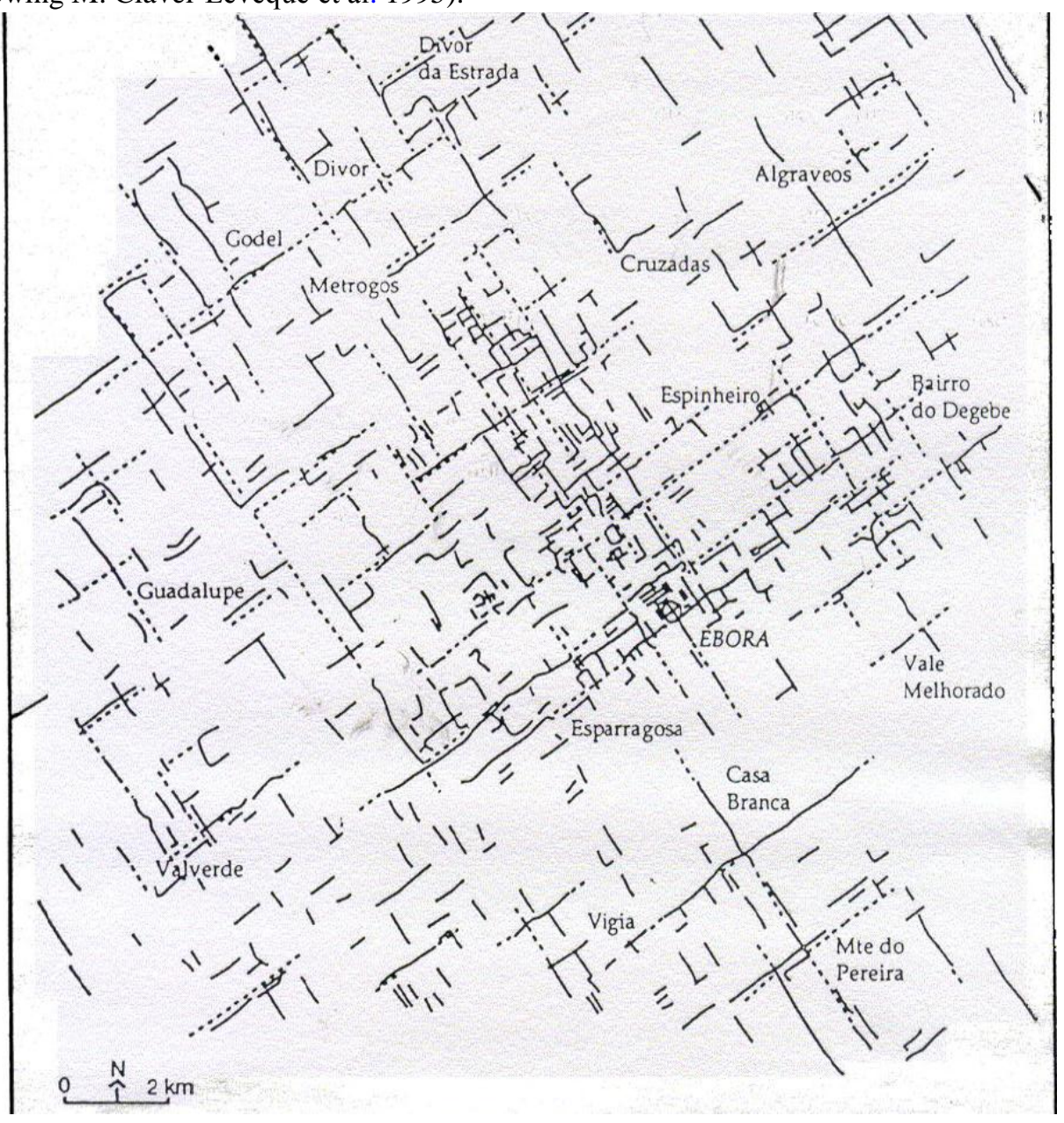

The Convent of Good Jesus, popularly known as Mitra, was built in the 16th century by Cardinal King Henry of Portugal. It was renovated and extended several times during the period up until the 18th century; of special interest are the works carried out by Archbishop Simão da Gama in 1706. The estate has a notable water management system featuring an aqueduct dating from the second half of the 17th century, a cistern, several water-tanks and kitchen-garden irrigation channels (Fig. 3). 


\section{Fig. 3: Oblique aerial photograph of the Mitra convent kitchen garden}

(photo J. M. de Mascarenhas 1985).

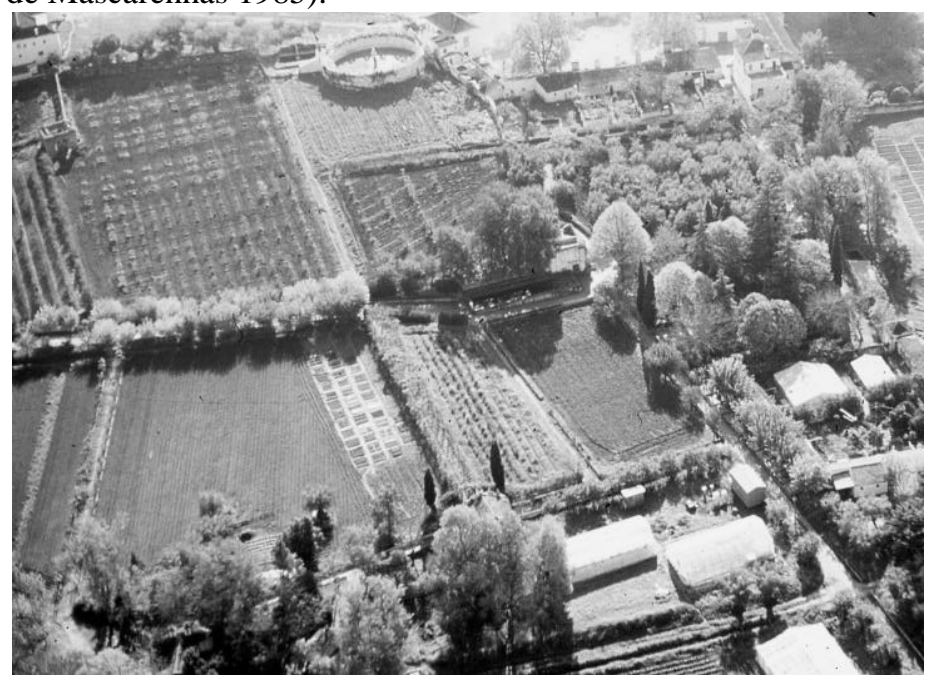

The upper Douro valley wine-producing region was granted World Heritage status by UNESCO in 2001. The landscape features slopes or terraces constructed by people on the sides of the valley of the River Douro and some of its tributaries. Dry-stone walls made of schist were traditionally used as part of the terrace structure and their permanent maintenance constitutes the main conservation measure required to be implemented in the landscape (Fig. 4).

According to the World Heritage Convention classification system, the second type of landscape is a "relict (or fossil) landscape", while the others are "continuing landscapes"; the ancient cadastration constitutes as a "hidden landscape".

Fig. 4: Douro terraced vineyard landscape (photo F. Peneiras 2009).

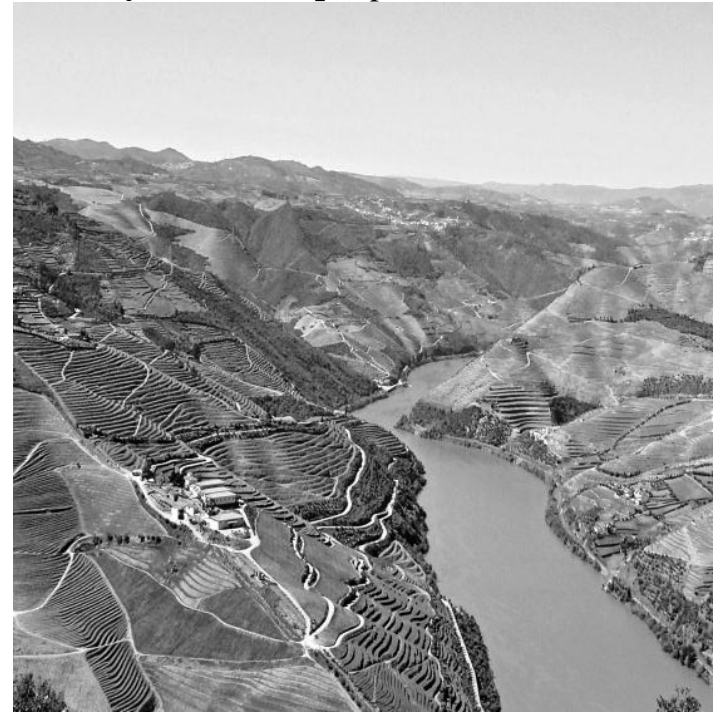




\section{The heritage evaluation of cultural landscapes}

What criteria should be used in heritage evaluation? In an attempt to address this question, Randall Mason (2002) presents the following summary of this controversial topic: "Should material culture recognized as heritage be said to have some intrinsic value (unchanging and universal), or should heritage value be seen as radically and essentially extrinsic and constructed out of the various contexts of the object, building or site? The answer seems to lie somewhere in between: value is formed in the nexus between ideas and things. The viewpoint adopted in this research borrows from both ends of this spectrum: on the one hand, everything anointed as heritage will, by definition, have some kind of heritage value, aside from whether the value is primarily historic, artistic, or social). In other words, anything defined as heritage is said to intrinsically and tautologically possess some kind of heritage value (though the nature of that value is not intrinsically given). On the other hand, the contingent/constructed viewpoint rightly points to value-formation factors outside the object itself and emphasises the important social processes of value formation. Recognizing the fundamental contingency of heritage values does not preclude the possibility of some values that are universally held (or nearly so)".

The need for evaluating cultural landscapes in terms of heritage is addressed by the European Landscape Convention "recognizing that, in a community and personal context, the most ordinary-looking landscape can be filled with values" (Fowler, 2006). Among these, heritage values should be assessed using specific landscape evaluation methods (Fig. 5).

Fig. 5: Landscape heritage value assessment process

(based upon Mason, 2002, Fig. 2 modified; drawing of C. Carriço)

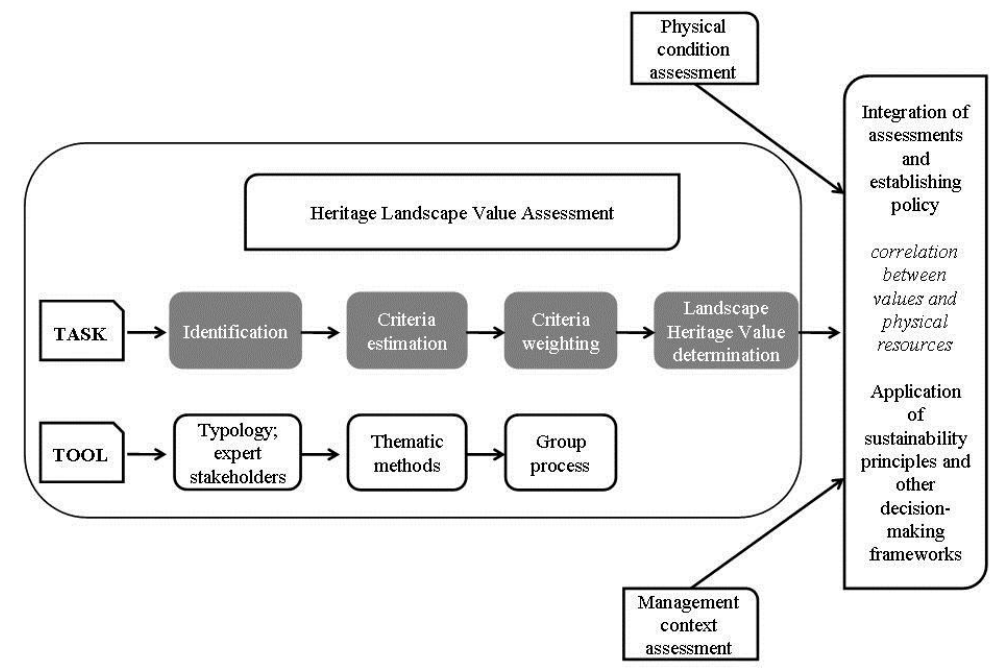

Setting priorities through the ranking of landscape heritage values is extremely useful for land planning purposes, especially landscape conservation, within a context of budgetary limitations. Landscape heritage value ranking aids decision-making for example in the field of monitoring priorities.

A range of criteria can be used for assessing landscape heritage values and in this paper a number of criteria were selected for trial, each being assigned a weighting coefficient in 
accordance with its relative importance (Table 1). Of course, this is an extremely delicate matter due to the subjectivity and contingency of most assessments, creating difficulties in the definition of criteria nomenclature and the development of a framework for the assessment and integration of different kinds of heritage values (Mason, 2002). Criteria should only be set and weighting coefficients selected following a wide-ranging debate involving experts.

Table 1: Criteria definition and heritage valuation of the landscapes study-cases

\begin{tabular}{|c|c|c|c|c|c|}
\hline Criteria & $\begin{array}{l}\text { Weighting } \\
\text { coefficient }\end{array}$ & $\begin{array}{l}\text { Montados of } \\
\text { holm and/or } \\
\text { cork oaks }\end{array}$ & $\begin{array}{l}\text { Ebora Augustan } \\
\text { roman cadastral } \\
\text { network }\end{array}$ & $\begin{array}{l}\text { Mitra } \\
\text { convent } \\
\text { kitchen } \\
\text { garden }\end{array}$ & $\begin{array}{l}\text { Douro terraced } \\
\text { vineyard } \\
\text { landscape }\end{array}$ \\
\hline $\begin{array}{l}\text { Built heritage (architectonic and } \\
\text { archaeological richness) }\end{array}$ & 3 & $\mathrm{~L}$ & ML & $\mathrm{H}$ & ML \\
\hline $\begin{array}{l}\text { Natural biotic heritage (vegetal and } \\
\text { animal richness) }\end{array}$ & 3 & MH & ML & $\mathrm{L}$ & $\mathrm{L}$ \\
\hline $\begin{array}{l}\text { Natural abiotic heritage } \\
\text { (palaeonthological, geological and } \\
\text { geomorphological) richness. }\end{array}$ & 3 & L & $\mathrm{L}$ & $\mathrm{L}$ & $\mathrm{L}$ \\
\hline Rarity of the heritage landscape type & 4 & ML & $\mathrm{H}$ & MH & $\mathrm{MH}$ \\
\hline $\begin{array}{l}\text { Antiquity of the coherent spatial } \\
\text { structures of the heritage landscape }\end{array}$ & 2 & $\mathrm{~L}$ & ML & $\mathrm{L}$ & $\mathrm{L}$ \\
\hline $\begin{array}{l}\text { Scientific potential: potential offered } \\
\text { by the heritage landscape concerning } \\
\text { the archaeological and/or historical } \\
\text { and/or geographical research. } \\
\text { Importance of the landscape to the } \\
\text { evolution or alteration of theories } \\
\text { actually accepted. }\end{array}$ & 4 & $\mathrm{H}$ & MH & MH & L \\
\hline $\begin{array}{l}\text { Recreation potential: potential offered } \\
\text { by the heritage landscape concerning } \\
\text { the amusement usufruct. }\end{array}$ & 1 & $\mathrm{H}$ & ML & $\mathrm{H}$ & $\mathrm{H}$ \\
\hline $\begin{array}{l}\text { Pedagogic potential : potential } \\
\text { offered by the heritage landscape } \\
\text { concerning the educational activity }\end{array}$ & 2 & MH & MH & MH & MH \\
\hline $\begin{array}{l}\text { Historic record: quality and } \\
\text { development of the realized landscape } \\
\text { research and of the related } \\
\text { documental production }\end{array}$ & 1 & $\mathrm{H}$ & $\mathrm{H}$ & ML & MH \\
\hline $\begin{array}{l}\text { Conservation statute: importance of } \\
\text { the classification statute if existing. }\end{array}$ & 3 & $\mathrm{H}$ & $\mathrm{L}$ & $\mathrm{L}$ & $\mathrm{H}$ \\
\hline $\begin{array}{l}\text { Symbolic importance: connection of } \\
\text { the heritage landscape with historical, } \\
\text { socio-economic and/or religious } \\
\text { events. }\end{array}$ & 2 & MH & MH & MH & $\mathrm{H}$ \\
\hline $\begin{array}{l}\text { Coherence degree of the spatial } \\
\text { structures related to certain(s) } \\
\text { epoch(s). }\end{array}$ & 4 & ML & $\mathrm{H}$ & $\mathrm{MH}$ & $\mathrm{MH}$ \\
\hline $\begin{array}{l}\text { Conservation degree of the spatial } \\
\text { structures of the heritage landscape } \\
\text { (identification marks) }\end{array}$ & 3 & MH & ML & MH & ML \\
\hline $\begin{array}{l}\text { Aesthetical quality of the heritage } \\
\text { landscape when observed from } \\
\text { terrestrial sites. }\end{array}$ & 2 & $\mathrm{H}$ & $\mathrm{L}$ & $\mathrm{H}$ & $\mathrm{H}$ \\
\hline $\begin{array}{l}\text { Monumentality : grandiosity of the } \\
\text { heritage landscape when observed } \\
\text { from terrestrial sites. It is in a great } \\
\text { extent reflex of the topographic } \\
\text { insertion of the spatial structures. }\end{array}$ & 2 & $\mathrm{H}$ & MH & ML & $\mathrm{H}$ \\
\hline $\begin{array}{l}\text { Range: surface occupied by the } \\
\text { heritage landscape }\end{array}$ & 2 & $\mathrm{MH}$ & $\mathrm{H}$ & $\mathrm{L}$ & $\mathrm{H}$ \\
\hline $\begin{array}{l}\text { Craft - or work - related value: } \\
\text { related with methods used to design } \\
\text { and built the landscape, and processes } \\
\text { of making }\end{array}$ & 2 & MH & $\mathrm{H}$ & MH & $\mathrm{H}$ \\
\hline
\end{tabular}


Nevertheless, simple semi-quantitative methods such as the linear combination function can be used. For conducting a methodological trial the landscapes described above were used (case-studies).

The importance of each landscape was assessed in accordance with each criterion and the results expressed in terms of a range of values, considering four classes of valuation (High; Medium-High; Medium-Low, and Low). Each criterion was assigned a weighting factor or coefficient due to the results of experiences in the field, workshops involving experts and theoretical considerations.

Using a general scale of values (a convenience scale), each class was assigned a numerical value, enabling the linear function application and heritage value (Y) to be obtained:

$$
\mathrm{Y}=\sum_{\mathrm{i}=1}^{\mathrm{n}} \mathrm{a}_{\mathrm{i}} \cdot \mathrm{X}_{\mathrm{i}}
$$

$\left(\mathrm{n}=\right.$ number of criteria; $\mathrm{a}_{\mathrm{i}}=$ weighting coefficient; $\mathrm{X}_{\mathrm{i}}=$ value concerning criteria $\left.\mathrm{i}\right)$

After conversion to a 0-100 scale, the following heritage values were obtained for each landscape: "montado" landscape: 55; Augustan Roman cadastral network: 54; Mitra kitchen-garden: 48; Douro terraced-vineyard landscape: 53. Thus the value of the four landscapes is very similar. On comparing the results of this survey, the initial reaction is of course to call into question the validity of the findings, but at the same time as far as heritage value is concerned the importance of fragile hidden landscapes that can and should be evaluated and preserved should be stressed; they are threatened by land management resulting in the ongoing auto-organisation of the landscape - the "transformission process", as Claire Marchand (2007) terms it.

A similar method based on a weighted linear combination was developed by the authors of this paper for the evaluation of certain criteria such as natural and built heritage values, and has already been applied successfully (Mascarenhas, 1995; Barata and Mascarenhas, 2002).

Local people should be involved the kind of land-planning actions and conservation processes described above. However, in view of the complexity of the scientific analytical methods applied, an effort should be made to ensure that all those involved: technical staff, researchers and the inhabitants of the local area have a shared understanding of the issues. "Stakeholders must have a knowledge of the values present in their landscape and must implement therefore management strategies" (Esposito and Cavelzani, 2006) in order to protect landscape heritage values. The global landscape qualification process should integrate the aspirations of the local people in question (Luginbühl, 2006); after all, they are the ones whose memory is paramount and who are guardians of the heritage.

\section{Heritage landscape monitoring indicators}

Heritage landscapes are frequently associated with fragile environments subject to damage resulting from human activities such as agriculture and tourism and natural phenomena like earthquakes. This is why it is so important the development of monitoring indicators in order to manage these areas.

The main reason for this is that "if major environmental impacts have already occurred at a particular site, it will generally be obvious that remedial works and rehabilitation will be 
required, and measures taken to prevent the impact recurring. Both these steps are likely to be expensive; and it may still prove impossible to rehabilitate the area fully. If the impact could have been predicted or detected at an earlier stage, and certainly before it reached any threshold of irreversible change, then it could have been overcome or avoided much more cheaply and easily. As with any tool-kit, preventive maintenance generally needs less effort and smaller tools than major repairs" (Buckley, 1998). Monitoring thus becomes then a critically important tool in landscape management. Land managers "need to devote more of their budgets to monitoring the state of the environment, and testing the effectiveness of management tools, before impacts become irreversible. The establishment of monitoring programs, and selection and application of management tools, are choices which can only be made by land managers" (Buckley, 1998).

With a cultural landscape in which there is a range of different heritage features, the definition of monitoring priorities is essential in the formulation of different types of landscape management plans such as the development of eco-cultural tourism projects, the setting up of cultural parks, and other kinds of projects which are feasible within a heritage landscape context.

These monitoring priorities can be established using the following four main criteria: heritage value; threatened occurrences; existing pressures; management and financing solutions.

The use of indicators constitutes a useful and pragmatic approach:

- for the regular monitoring of the decline in heritage landscape quality as a result of:

- natural events;

- social and economic activities, including tourism.

- for the regular setting of monitoring priorities.

The importance of indicators as tools for sustainable resource management was highlighted in Agenda 21 of the UN Conference on Environment and Development in 1992. They can give a good idea of changes in the magnitude of parameters, identify the related processes and provide a "framework for setting targets and monitoring performance" (Li, 2004).

The Pressure-State-Response (PSR) conceptual model, approved in 1995 by the OECD and the UNEP (Hammond, 1995), was adopted in 1996 by the UN Commission on Sustainable Development and the UN Department for Policy Coordination and Sustainable Development for the establishment of sustainable development indicators ( $\mathrm{Li}, 2004)$. In the beginning the model was conceived in a tourism management context. Nevertheless it can be adapted to heritage landscape quality management in a more general situation, involving other socio-economic activities such as agriculture, forestry and land management projects, and natural events, like floods, hurricanes and global change, with impact on landscape quality.

According to the model (Fig. 6), state indicators are related with the heritage quality state of the landscape, pressure indicators are associated with the impacts of human activities and natural events on heritage landscape quality and response indicators are concerned with manager responses (measurements, regulations and standards) for controlling and preventing the decline in landscape heritage quality. 


\section{Fig. 6: Pressure-State-Response (PSR) model in a wide context}

(source: Coccossis et al., 2001)

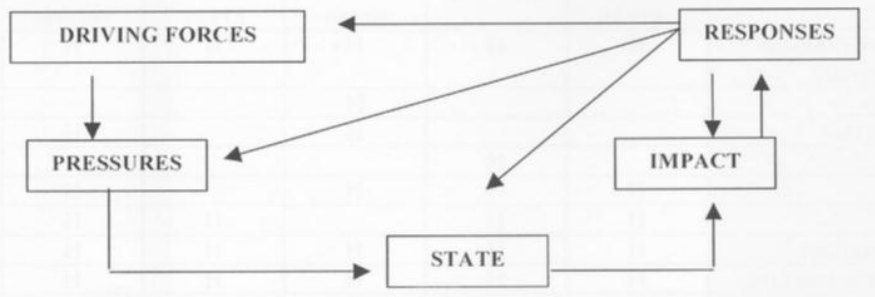

In this paper, only a few specific monitoring state indicators providing information on heritage quality were selected. Other types of indicator could also be considered for the evaluation of landscape heritage such as "host community perceptions of visitor/user impacts"; however, this indicator was not selected (Table 2) due to its lack of applicability to the case-studies used.

\section{Table 2: Monitoring indicators of heritage landscapes: a proposal}

\begin{tabular}{|c|c|c|}
\hline Indicator & Description & Monitoring action \\
\hline Legal protection & $\begin{array}{l}\text { Heritage features (natural/cultural); } \\
\text { legal status of protection }\end{array}$ & $\begin{array}{l}\text { Number of protected sites } \\
\text { (natural/cultural) versus to those } \\
\text { without any protection }\end{array}$ \\
\hline $\begin{array}{l}\text { Maintenance of original } \\
\text { functions }\end{array}$ & $\begin{array}{l}\text { Concerns the measure of the } \\
\text { deviation of the actual landscape } \\
\text { systems from the traditional ones. }\end{array}$ & $\begin{array}{l}\text { Ratio between altered area and the } \\
\text { global area; affectedness degree } \\
\text { evaluation based on the quality of } \\
\text { the alteration }\end{array}$ \\
\hline Social involvement & $\begin{array}{l}\text { Related with the capability of the } \\
\text { landscape system to involve local } \\
\text { people in its management (creation } \\
\text { of employment) }\end{array}$ & $\begin{array}{l}\text { Number of employees versus the } \\
\text { area of the park (or the parish } \\
\text { population) }\end{array}$ \\
\hline Cultural heritage conditions & $\begin{array}{l}\text { Deals with the inventoried heritage } \\
\text { structures or areas, and good state of } \\
\text { maintenance of these elements } \\
\text { (implies the previous definition of } \\
\text { the heritage values and of the } \\
\text { intervention hierarchy) }\end{array}$ & $\begin{array}{l}\text { Number of good state } \\
\text { f maintenance heritage elements } \\
\text { versus total number of heritage } \\
\text { elements. } \\
\text { Concerning heritage landscape the } \\
\text { comparison is between areas. }\end{array}$ \\
\hline Man made damages & $\begin{array}{l}\text { Wears and tears marks in heritage } \\
\text { features. }\end{array}$ & $\begin{array}{l}\text { Evaluation of the affectedness } \\
\text { degree considering also the } \\
\text { number of affected structures (or } \\
\text { areas) versus the total }\end{array}$ \\
\hline Erosion & $\begin{array}{l}\text { Existence of marks resulting from } \\
\text { the erosion natural processes }\end{array}$ & idem \\
\hline Corrosion & $\begin{array}{l}\text { Deal with marks in heritage features } \\
\text { caused by pollutants (soil, air and } \\
\text { water) }\end{array}$ & idem \\
\hline Phyto-sanitarian quality & $\begin{array}{l}\text { Related mainly with phyto-sanitarian } \\
\text { conditions of vegetation structures, } \\
\text { such as vegetation galleries, rare } \\
\text { plants and others valued formations }\end{array}$ & \\
\hline Biotope quality and diversity & $\begin{array}{l}\text { Deals with the vegetation and the } \\
\text { fauna habitats quality, and the level } \\
\text { of biodiversity degree }\end{array}$ & Affectedness degree evaluation \\
\hline Safety & $\begin{array}{l}\text { Deals with security and protection } \\
\text { conditions of the area }\end{array}$ & $\begin{array}{l}\text { Existence of personal and/or } \\
\text { instrumental safety systems and } \\
\text { their quality }\end{array}$ \\
\hline
\end{tabular}


As heritage landscapes can display extremely diverse and contrasting characteristics as far as their nature, characteristics and range are concerned, some indicators which appear in Table 2 are not applicable for some landscapes types. Applicability trials should therefore be carried out with the aim of determining those with the most universal character.

The applicability of selected indicators to the four heritage landscape case-studies is presented in Table 3. It is evident that the only monitoring indicators with universal applicability in terms of heritage landscape were: legal protection, cultural heritage conditions, man made damages, corrosion and phyto-sanitary quality. This is due to the high level of typological diversity of heritage landscapes, which varies from region to region, country to country and continent to continent. To find monitoring indicators whose applicability is universal, that is, which can be used with any region or landscape, is a very important issue. Nevertheless, regional indicators may be sometimes very useful. The conducting of further trials in different landscapes will lead to the development of a more accurate selection process and the worldwide applicability of indicators.

Table 3: Monitoring indicators of heritage landscapes quality: Essay of applicability to the four landscape study-cases.

\begin{tabular}{|c|c|c|c|c|}
\hline Indicator & $\begin{array}{l}\text { Mitra kitchen } \\
\text { garden }\end{array}$ & $\begin{array}{l}\text { Ebora roman } \\
\text { Cadastration }\end{array}$ & $\begin{array}{l}\text { Mitra } \\
\text { "Montado" }\end{array}$ & $\begin{array}{l}\text { Douro terrace } \\
\text { landscape }\end{array}$ \\
\hline Legal protection & Yes & Yes & Yes & Yes \\
\hline $\begin{array}{l}\text { Maintenance of original } \\
\text { functions }\end{array}$ & Yes & No & Yes & Yes \\
\hline Social involvement & Yes & No & Yes & Yes \\
\hline $\begin{array}{l}\text { Cultural heritage } \\
\text { conditions }\end{array}$ & Yes & Yes & Yes & Yes \\
\hline Man made damages & Yes & Yes & Yes & Yes \\
\hline Erosion & No & Yes & Yes & Yes \\
\hline Corrosion & Yes & Yes & Yes & Yes \\
\hline $\begin{array}{l}\text { Phyto- sanitarian } \\
\text { quality }\end{array}$ & Yes & Yes & Yes & Yes \\
\hline $\begin{array}{l}\text { Biotope quality and } \\
\text { diversity }\end{array}$ & No & Yes & Yes & No \\
\hline Safety & Yes & No & № & No \\
\hline
\end{tabular}

\section{RESULTS AND CONCLUSIONS}

The experience of the estimation of heritage landscape values and monitoring indicators presented in this paper merely serves as rough guide. The narrow range of values produced in the results of the evaluation of the different heritage landscapes used may seem surprising and conditions any discussion as to which indicators should be selected. In our survey, the same range of evaluation classes was used for each criteria so there is ample scope for subjectivity, which may be reduced if different classes are used; the larger the number of classes used the more accurate the final result will be.

One of most important aspects of the model, as mentioned above, is its universality of applicability. If improvements are made to the model in terms of reliability it could be 
applied to any region or landscape. Thus further trials will need to be conducted in different landscapes and then the model could be applied all over the world.

In this paper the initial question asked is: why do cultural landscapes have different values? Heritage landscape signifies the different ways in which mankind in general and individual communities in particular connect with nature and environment: each community has its own specific cultural, technical - even moral - background and historical experience.

The differences are apparent, and the closer the view we take, the more we become aware that they result from different human achievements and activities. The use of monitoring indicators raises our awareness of these differences and helps us to understand how far they are the result of human activity.

\section{ACKNOWLEDGEMENTS}

We are grateful for the support provided by the CIDEHUS research centre at Évora University, and we would also like to thank Mr. Fernando Peneiras for lending the photograph of the Douro valley and Ms. Cristina Carriço for the drawing in Figure 5.

\section{REFERENCES}

Aplin, G. (2007). World Heritage Cultural Landscapes. International Journal of Heritage Studies, 13 (6): 427-446.

Audrerie, D. (1997). La notion et la protection du patrimoine. Presses Universitaires de France, Paris.

Barata, F.T., Mascarenhas J. M. De (2002). Preservando a Memória do Território / Preserving the Land's Memories. Centro de Estudos de Ecossistemas Mediterrânicos, Universidade de Évora, Évora.

Buckley, R. (1998). Tools and Indicators for Managing Tourism in Parks. Annals of Tourism Research, 25 (4): 208-211.

Clavel-lévêque, M., Plana-mallart, R. \& Vignot, A. (1995). Évora - Partie I: La ville romaine d'Ebora et son territoire; Partie II : Organisation et aménagement de l'espace rural; Partie III : Approche morphologique et cartographique des images satellitaires. In: Mascarenhas, J.M. de (COORD), 1995: Análise da Região Envolvente de Évora numa perspectiva de Ecologia da Paisagem. Relatório do Projecto STRIDE, Vol.3 (Anexo I). Universidade de Évora: Centro de Estudos de Ecossistemas Mediterrânicos, Évora. Unpublished internal report.

Coccossis, H., Mexa, A., Parpairis, A. \& Konstandoglou, M. (2001). Defining, Measuring and Evaluating Carrying Capacity in European Tourism Destinations. Report B43040/2000/294577/MAR/D2. University of the Aegean, Athens. Accessed August 2010, from: http://ec.europa.eu/environment/iczm/pdf/tcca_en.pdf

De la Torre, M., Mason, R. (2002). Introduction. In: De La Torre, M. (Ed.): Assessing the Values of Cultural Heritage, pp 3-4. The Getty Conservation Institute, Los Angeles,

Eagles, P. F. J., Mccool, S. F. \& Haynes, C. D. A. (2002). Sustainable Tourism in Protected Areas: Guidelines for Planning and Management. IUCN, Gland (SW) and Cambridge (UK). 
Esposito, M., Cavelzani, A. (2006). The World Heritage and cultural landscapes. PASOS. Revista de Turismo y Patrimonio Cultural, 4 (3): 409-419.

Fowler, P. (2006). World Heritage Cultural Landscapes: What are they? World Heritage Review, 44. Accessed August 2010, from, http://whc.unesco.org/uploads/activities/ documents/activity-477-2.doc

Hammond, A. (1995). Environmental Indicators: A systematic approach to measuring and reporting on environmental policy performance in the context of sustainable development. World Resource Institute, Washington.

Li, W. (2004). Environmental management indicators for ecotourism in China's nature reserves: A case study in Tianmushan Nature Reserve. Tourism Management, 25: 559-564.

Lowenthal, D. (1993). Landscape as Heritage: National Scenes and Global Changes. In: Fladmark, J.M. (Ed.): Heritage: Conservation, Interpretation and Enterprise. pp 3-15. Donhead, London,

Luginbühl, Y. (2006). Paysage et identification, qualification et objectifs de qualité. In: Dejeant-pons, M., Buergi, E. (Dirs): Paysage et développement durable: les enjeux de la Convention européenne du paysage. pp 107-125. Conseil de l'Europe, Strasbourg

Marchand, C. (2007, September). Que faire de l'héritage? Les Actes du Premier Colloque d' Archéogéographie (Paris), Accessed August 2010, from http://www.archeogeographie .org/ index.php? rub=bibli/ colloques/pre-actes/marchand.

Mascarenhas, J. M. De. (1995). ÉVORA: Archéologie et Conservation du Paysage Environnant. In: Clavel - Lévêque, M., Plana-Mallart, R. (Eds.): Cité et Territoire. pp 227230. Ier. Colloque Européen, Béziers, 1994. Annales Littéraires de l'Université de Besançon, $565 \mathrm{p}$.

Mascarenhas, J. M. DE. (COORD) (1995). Análise da Região Envolvente de Évora numa perspectiva de Ecologia da Paisagem. Relatório do Projecto STRIDE. Universidade de Évora: Centro de Estudos de Ecossistemas Mediterrânicos, Évora. Unpublished internal report.

Mason, R. (2002). Assessing Values in Conservation Planning: Methodological Issues and Choices. In: De la Torre, M. (Ed.): Assessing the Values of Cultural Heritage, pp 5-30. The Getty Conservation Institute, Los Angeles

Merriman, N. (1996). Understanding Heritage. Journal of Material Culture, 1(3): 377-386.

WHC (2005). Operational Guidelines for the Implementation of the World Heritage Convention. Document WHC. 05/2. UNESCO World Heritage Centre, Paris 